\title{
Hermeneutika Emillio Betti dan Aplikasinya dalam Menafsirkan Sistem Kewarisan 2:I pada Surat an-Nisa Ayat I I
}

\author{
Labib Fahmi* \\ Sekolah Tinggi Sains Islam Bina Cendekia Utama Cirebon \\ Email: labibfahmi35@gmail.com
}

\begin{abstract}
One characteristic of the inheritance system in Islamic law that distinguishes it from other inheritance systems is that there are differences in division between the male and female parts, as stated in the Koran in Surat an-nisa verse 11, namely the male part is equal to two part of women, this rule seems to have been standardized in the study of various fiqh in various schools of thought that are mu'tabaroh. Even the system has been standardized and recognized legally in the Religious Courts throughout Indonesia through the legalization of the Compilation of Islamic Law in Indonesia which is required to be used throughout the Religious Courts in the country. Not only legal and recognized in the Religious Courts, but also several cases of dispute resolution outside the court also hold fast to the text of the verse 11 paragraph in resolving inheritance disputes committed by several legal experts'/community leaders outside the court. This paper shows a interpretation from the another perspective with hermeneutic of Emmilio Betti. She was a philosopher, theologian and legal expert from Italy, a figure of hermeneutics apad 19 who adheres to the principle of verstehen as a form of understanding that can be traced and justified methodologically that is objective interpretation that can be used as the basis of science, for Betti, meaning should be derived from the text and not included in the text.

Using Hermeneutics Betti in interpreting this verse will produce a verstehen, that the meaning of verse 11 of the epistle must also be related to the cause of revelation in solving this inheritance problem comprehensively and objectively, regardless of this verse can be used as a
\end{abstract}

* Dosen Program Studi Ekonomi Syariah di Sekolah Tinggi Sains Islam Bina Cendekia Utama Cirebon. 


\title{
$144 \mid$ Labib Fahmi
}

textual context or the context of the verse want a settlement of inheritance according to revelation, and the Prophet has proven that the verse can fulfill the justice of the friends who ask about the distribution of inheritance among friends.

Keywords: Islamic Inheritance System, Hermeneutics, Emillio Betti

\begin{abstract}
Abstrak
Salah satu ciri khas sistem kewarisan dalam hukum islam yang membedakan dengan sistem kewarisan lainya adalah ada perbedaan pembagian antara bagian laki-laki dan bagian perempuan, sebagaimana disebutkan dalam al-Quran dalam surat an-nisa ayat 11 yaitu bagian lakilaki adalah sama dengan dua bagian perempuan, aturan ini seakan sudah dibakukan dalam kajian berbagai fikih di berbagai madzhab yang mu'tabaroh. Bahkan sistem tersebut sudah dibakukan dan diakui legal di Pengadilan Agama di seluruh Indonesia melalui legalisasi Kompilasi Hukum Islam di Indonesia yang diwajibkan penggunaanya di seluruh Pengadilan Agama di tanah air. Tidak hanya legal dan diakui di Pengadilan Agama, namun juga beberapa kasus penyelesaian sengketa di luar pengadilan juga tetap berpegang teguh pada teks surat an-nisa ayat $11 \mathrm{ini}$ dalam menyelesaikan sengketa waris yang dilakukan oleh beberapa ahli hukum/tokoh masyarakat di luar pengadilan. Tulisan ini berusaha untuk menghadirkan kajian tersebut diatas dari perspektif berbeda dengan menggunakan pendekatan studi hermeneutika Emmilio Betti. Ia seorang filusuf, teolog dan ahli hukum dari italia, tokoh hermeneutika apad 19 yang berpegang pada prinsip verstehen sebagai sebuah bentuk pemahaman yang bisa ditelusuri dan dibenarkan secara metodologis yaitu penafsiran yang obyektif-lah yang dapat dijadikan dasar ilmu pengetahuan, Bagi Betti, makna seharusnya diderivasi dari teks dan bukan dimasukkan ke dalam teks. Menggunakan Hermeneutika Betti dalam menafsirkan ayat ini akan menghasilkan sebuah pemikiran, bahwa makna ayat 11 surat an-nisa harus juga dikaitkan dengan sebab sebab turunya wahyu dalam penyelsaian masalah waris ini secara komprehensif dan obyektif, terlepas ayat ini dapat dijadikan secata tekstual ataupun konteks turunya ayat yang menginginkan penyelesaian waris menurut wahyu, dan Nabi sudah membuktikan bahwa ayat tersebut dapat memenuhi keadilan para sahabat yang bertanya tentang pembagian waris di kalangan sahabat.
\end{abstract}

Kata Kunci: Sistem Waris Islam, Hermeneutika, Emillio Betti 


\section{Pendahuluan}

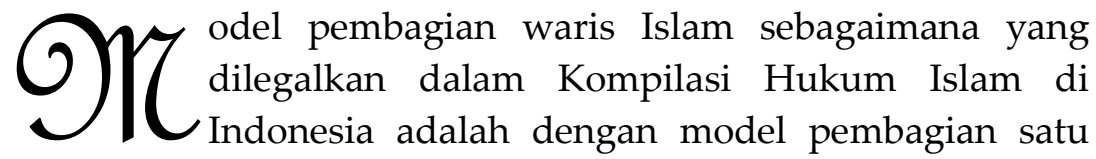
bagian untuk ahli waris anak perempuan dan dua bagian untuk ahli waris anak laki laki, atau dikenal dengan istilah dua banding satu (2:1), ini adalah sesuai atau sama persis seperti yang tertulis dalam kitab Suci al-Quran Surat an-Nisa ayat 11.

Pembagian model ini juga berlaku diseluruh Pengadilan Agama yang berada di Indonesia, sebab sumber rujukan wajib bagi Pengadilan Agama dalam memutus perkara waris adalah buku Kompilasi Hukum Islam yang diinpreskan oleh Presiden pada tahun 1992. Perkara pembagian harta waris yang diputus oleh pengadilan agama selalu didasarkan kepada model yang sudah dilegalkan dalam Kompilasi Hukum Islam yaitu salah satunya prinsip dua banding satu, model ini ditaati sebagai model pembagian yang sudah final dan berkekuatan hukum tetap. Dalam pasal 176 yang berbunyi:

Anak perempuan bila hanya seorang ia mendapat separuh bagian, bila dua orang atau lebih mereka bersama-sama mendapat dua pertiga bagian, dan apabila anak perempuan bersama-sama dengan laki laki, maka bagian anak laki laki dua berbanding satu dengan anak perempuan. ${ }^{1}$

Pasal tersebut secara gambling menjelaskan bahwa lakilaki mendapatkan bagian dua kali lipat dari bagian anak perempuan, atau dalam istilah jawa diterjemahkan dengan sepikul segendongan, laki-laki dapat satu pikul dan anak perempuan dapat hanya satu gendongan.

Kenyataanya pembagian waris dimasyarakat tidak selalu merujuk kepada pasal $176 \mathrm{ini}$, sebab penggunaan pasal 176 hanya mengikat ketika terjadi perselisihan dan diselesaikan di

\footnotetext{
${ }^{1}$ Kompilasi Hukum Islam, pasal 176
} 
$146 \mid$ Labib Fahmi

Pengadilan Agama saja, adapun penggunaan pasal tersebut tidak dapat diberlakukan kepada penyelsaian kasus waris yang terdapat dimasyarakat, menurut hemat penulis, model pembagian waris di masyarakat mengacu langsung kepada penafsiran surat an-Nisa ayat 11 yang berisi tentang bagian lakilaki lebih besar dua kali lipat dibanding dengan bagian waris anak perempuan apabila kedua-duanya berada dalam satu ahli waris. Ada masyarakat yang menggunakan pembagian sama rata meskipun mereka menerima model pembagian waris dua banding satu, meski tidak melakukan model pembagian itu.

Hazairin dalam bukunya menulis bahwa sistem waris yang berlaku di Indonesia dikelompokan menjadi tiga yaitu:

Pertama, sistem kewarisan individual, yang cirinya ialah bahwa harta peninggalan dapat dibagi-bagikan pemiliknya di antara ahli waris seperti dalam masyarakat bilateral Jawa dan Patrinial di Tanah Batak.

Kedua, sistem kewarisan kolektif, yaitu cirinya ialah harta peninggalan diwarisi oleh sekumpulan ahli waris yang merupakan semacam badan hukum dimana harta tidak bolah diwariskan kepada ahli waris.

Ketiga, sistem kewarisan mayorat, yaitu anak pewaris yang tertua adalah pemegang hak waris sepenuhnya terhadap harta peninggalan seperti dalam masyarakat adat Bali. ${ }^{2}$

Penafsiran model Hazairin ini menurut penulis merupakan telaah yang kondisional pada kultur masyarakat arab sendiri dan apa yang dijadikan solusi oleh al-Quran terhadap solusi penyelesaian masyarakat arab serta ada tujuan yang diinginkan oleh al-Quran dalam memberikan konsep pembagian waris tersebut. Namun meskipun apa yang telah dilakukan oleh Hazairin sudah dapat menunjukan bahwa model pembagian waris dalam al-Quran adalah menganut sistem waris

2 Hazairin, Hukum Kewarisan Bilateral menurut Quran dan Hadith, (Jakarta: Tintamas Indonesia, 1981), 15.

Ulul Albab: Jurnal Studi dan Penelitian Hukum Islam 
bilateral sebagaimana. Menjadi kesadaran penulis adalah bagaimana seandainya melihat sisi lain dari pembagian waris ini dalam perspektif yang berbeda dengan Hazairin yaitu model hermeneutika yang dikembangkan oleh Emillio Betti.

\section{Pembahasan}

Sejak abad 19 (atau akhir abad 18), hermeneutika telah menemukan bentuknya yang baru dari wajah hermeneutika sebelumnya. Secara periodik hermeneutika dapat dibedakan dalam tiga fase; klasik, pertengahan, dan modern. Hermeneutika Klasik, lebih bercorak pada bentuk interpretasi teks dan 'art of interpretation'. Istilah ini pertama kali muncul pada abad ke 17. Tetapi hermeneutik dalam arti sebagai aktivitas penafsiran telah lahir jauh sebelumnya, usianya setua dengan eksegesis teks. ${ }^{3}$

Hermeneutika pertengahan, dimulai pada dan dianggap berasal dari penafsiran terhadap Bible yang menggunakan empat level pemaknaan baik secara literal, allegoris, tropological (moral), dan eskatologis. Tetapi pada masa reformasi protestan, empat pemaknaan itu kemudian disempitkan pada eksegesis literal atau gramatical dan eksegesis studi tentang Yahudi dan Yunani. Dan hermeneutika Modern, dapat dibedakan dalam beberapa fase dengan aliran-aliran yang mengikutinya. Fase awal, mulai pada abad ke 19 dengan merujuk pada tokoh protestan ternama, Friedrich Schleiermacher (1768-1834) dan murid-muridnya termasuk Emilio Betti, dengan teori hermeneutiknya (hermeneutical theory).

Fase kedua, pada abad ke-20 dengan Martin Heidegger (1889-1976) sebagai tokohnya, termasuk di sini Hans-George Gadamer dengan aliran filsafat hermeneutik (philosophical hermeneutic), dan terakhir adalah Jürgen Habermas, dengan hermeneutik kritiknya (critical hermeneutics).

${ }^{3}$ Mudjirahardjo, Hermeneutika Gadamerian Kuasa Bahasa dalam Wacana Politik Gus Dur, (Malang: UIN Malang Press, 2007), 88. 
$148 \mid$ Labib Fahmi

Priodeisasi hermeneutik di atas, tidak hanya menjelaskan babakan-babakan sejarah hermeneutik tapi juga menggambarkan suatu kecenderungan bagi corak dan karakteristik yang menandai lahirnya hermeneutik. Istilah hermenutik berasal dari bahasa Yunani, dari kata kerja hermeneuein yang berarti menginterpretasi. ${ }^{4}$

Salah satu metode penting untuk memahami sebuah naskah teks adalah dengan menggunakan pendekatan hermeunetika, baik teks tersebut adalah teks kesusteraan maupun teks yang bersifat suci dan sakral yang diturunkan kepada manusia dari wahyu, Istilah hermenutik berasal dari bahasa Yunani, dari kata kerja hermeneuein yang berarti menginterpretasi. Istilah ini memiliki asosiasi etimologis dengan dewa Hermes dalam mitologi Yunani, yang mempunyai tugas menyampaikan dan menjelaskan pesan-pesan Tuhan kepada manusia. Hermes diasosiasikan dengan fungsi mentransmusi apa di balik pemahaman manusia ke dalam suatu bentuk di mana tingkat intelejensia manusia dapat menangkap hal tersebut. Nampak, bahwa dari asosiasi etimologis ini tugas hermeneutika adalah membuat pesan supaya dapat dipahami secara baik oleh audiens. ${ }^{5}$

\section{Biografi Emilio Betti \& Tokoh yang Mempengaruhinya}

Emilio Betti adalah seorang filsuf, teolog dan ahli hukum dari Italia yg lahir pada tahun (1890-1968). Sumbangan pemikirannya untuk memajukan hermeneutika dalam tradisi pemikiran Barat amat berarti, khususnya di wilayah akademis berbahasa Italia dan Jerman. Kisah hidup Betti cenderung tertutup untuk diakses publik, khususnya khalayak yang berbahasa Inggris. Akan tetapi, dari keterangan yang diberikan

\footnotetext{
${ }^{4}$ Ibid, 89.

${ }^{5}$ Ibid, 90 .
}

Ulul Albab: Jurnal Studi dan Penelitian Hukum Islam 
oleh Josef Bleicher dan Richard Palmer6, kita bisa melihat bahwa ada sejumlah pemikir yang mempengaruhinya. Dalam hal hermeneutika, ada pengaruh Dilthey dan Schleiermacher, juga pemikiran Hegel dan Husserl serta pemikir neo-Kantian seperti Nicolai Hartmann.

Dalam filsafat bahasa, Betti banyak dipengaruhi oleh $\mathrm{W}$. Von Humboldt. Betti termasuk kategori pemikir hermeneutika yang berhaluan idealis-romantis. Pendekatan ini mengarahkan Betti untuk berargumentasi tentang kemungkinan verstehen sebagai sebuah bentuk pemahaman yang bisa ditelusuri dan dibenarkan secara metodologis. Pendekatan ini pula yang membuatnya berseberangan dengan Gadamer dalam hal menegaskan status epistemologis hermeneutika. Apa yang dilakukan oleh Betti merupakan argumentasinya untuk membela status objektif dari penafsiran guna sampai pada verstehen yang valid. Hampir keseluruhan karyanya ditulis dalam bahasa Italia. Terjemahan karyanya ke dalam bahasa Inggris, sayangnya, masih sangat amat terbatas.

Dukungan intelektual Betti tentang fasisme antara akhir Perang Dunia I dan awal tahun 1920-an menyebabkan dia ditangkap pada tahun 1944, di Camerino. Betti di penjara selama sekitar satu bulan, seperti yang diputuskan oleh Comitato di Liberazione Nazionale. Pada bulan Agustus 1945, Betti terbebas dari segala tuduhan. Pilihan politiknya, bagaimanapun, tidak mengurangi nilai dan pentingnya karyanya. Antara banyak hal lainnya, Betti adalah salah satu anggota komisi penyusunan perdata Italia dari tahun $1942 .{ }^{7}$

\section{Pokok Pemikiran Hermeneutika Emilio Betti}

\section{Interpretasi Objektif Melalui Canon-Canon}

6 Richard E. Palmer, Hermeneutics: Interpretation Theory in Schlemeiermacher, Dilthey, Heidegger, and Gadamer, (Evanston: Northwestern University Press, 1969), 46.

${ }^{7}$ Wikipedia, (diakses 30 November 2017)

Vol. 2, No. 1, Oktober 2018, 143-173 
$150 \mid$ Labib Fahmi

Hermeneutika dalam pandangan Betti merupakan teori umum penafsiran yang berfungsi sebagai metodologi umum untuk ilmu humaniora (Geisteswissenschaften). Ini sekaligus menunjukkan hermeneutika Betti sangat terinspirasi oleh hermeneutika Dilthey. Betti juga mengikuti pendapat Schleiermacher ketika menyatakan penafsiran memberlakukan kembali pikiran pengarang yang menggiring kepada pengetahuan kembali apa yang pada asalnya diteliti oleh pengarang. Sekalipun Betti terinspirasi oleh Schleiermacher, namun ini tidaklah menunjukkan Betti tidak memiliki kontribusi ide dalam hermeneutika. Di antara sumbangan penting gagasan Betti terhadap hermeneutika adalah:

Pertama, Betti menawarkan tipologi penafsiran yang komprehensif. Kedua, Ia adalah teoris yang pertama mendirikan institusi untuk mengkaji isu-isu penafsiran yang ditemukan dalam berbagai ranah keilmuan. Ia mendirikan Institut Penafsiran di Universitas Roma. ${ }^{8}$

Betti memulai hermeneutikanya dari pengamatan bahwa manusia memiliki kebutuhan alami untuk saling mengerti. Kebutuhan ini berangkat dari kemanusiaan umum yang semua manusia ikut serta. Seseorang 'mohon' kepada yang lain, mengeluarkan 'panggilan' kepada mereka untuk berusaha memahaminya. Ketika seseorang mengeluarkan permohonan untuk dimengerti, secara alami orang lain terpanggil dengan permohonan itu, dan secara alami pula merasa berkewajiban untuk menjawabnya. Seperti yang dikatakan oleh Betti:

"Nothing is as close to the heart of a human being as mutual understanding with other human beings." 9

Bagaimanapun, Emilio Betti berpendapat permohonan seseorang untuk dimengerti, tidak pernah dibuat secara

${ }^{8}$ Arif Ali Nayed, "Interpretation as the Engagement of Operatoional Artifacts: Operational", Disertasi Doktor, (Canada: Universitas Guelph, 1994).

${ }^{9} \mathrm{Ibid}, 37-38$.

Ulul Albab: Jurnal Studi dan Penelitian Hukum Islam 
langsung, tetapi hanya melalui perantara. Betti menyebutnya perantara tersebut sebagai 'bentuk-bentuk yang penuh makna (meaning-full forms). Konsep tentang bentuk-bentuk yang mewakili sangat penting dalam hermeneutika Betti.

Bagi Emilio Betti, makna itu sebagaimana yang dimaksudkan oleh pengarang dan agen-agen historis. Makna dirujuk kepada bentuk-bentuk yang penuh makna yang merupakan objektifkasi pemikiran manusia. Bagi Emilio Betti, terutamanya melalui bentuk-bentuk bahasa yang objektif dan struktur tingkah laku subjek yang menafsirkan menemukan akal yang lain. Bagi Emilio Betti, hermeneutika adalah metode yang diaplikasikan kepada penafsiran dalam menjamin objektiftas hasilnya. Dengan menggunakan metode yang benar serta norma penafsiran yang benar, seorang penafsir mampu untuk meraih di luar kondisi historisnya untuk memahami makna sebuah teks sebagaimana yang dimaksudkan oleh pengarang. Aturanaturan dan norma-norma yang mengarahkan penafsiran dapat diaplikasikan secara universal kepada teks apapun. ${ }^{10}$

Emilio Betti merumuskan metode serta norma dalam penafsiran yang akan mengantarkan seseorang untuk meraih objektiftas. Untuk mencapai tujuan tersebut, Emilio Betti melakukan 2 hal.

Pertama, ia mengklarifkasi persoalan pemahaman dengan memeriksa, secara detil proses penafsiran;

Kedua, memformulasi sebuah metodologi yang menghalang gangguan-gangguan subjektifs masuk ke dalam penafsiran objektif dari objektivitas akal. ${ }^{11}$

Betti memaknai pemahaman sebagai "sensus non est

10 Osman Billen, The Historicity of Understanding and The Problem of Relativism in Philosophical Hermeneutics, (Wahsingthon: The Council for Research in Values and Philoshophy, 2000), 91.

11 Josef Bleicher, Hermeneutika Kontemporer: Hermeneutika sebagai Metode, Filsafat dan Kritik, diterjemahkan oleh Ahmad Norma, (Yogyakarta: Fajar Pustaka Press 2013), 31. 
$152 \mid$ Labib Fahmi

inferendus sed efferendus", Betti menganggap hanya Auslegung (penafsiran objektif) sebagai bentuk sah dari penafsiran. Ini berbeda dengan Deutung dan "spekulative Deutung" (penafsiran spekulatif). ${ }^{12}$

Bagaimanapun, objektiftas yang sempurna bagi Emilio Betti tidak akan pernah diraih. Emilio Betti menegaskan yang ada hanya objektiftas yang relatif (relative objectivity). Bagi Emilio Betti, hal ini disebabkan adanya hubungan yang dialektis antara aktualitas pemahaman (actuality of understanding) dan objektivitas-objektivitas akal (objectivations of mind). Maksudnya, subjek dan objek, dalam proses penafsiran terkunci bersama dalam hubungan yang bertentangan. Akal telah mengental ke dalam bentuk yang permanent dan berkonfrontasi dengan subjek sebagai yang lain (other). Namun, antara keduanya (subjek dan objektivitas akal) memiliki saling keterkaitan. Oleh karena itu, akal yang subjektif memerlukan objektivitas sebagai penguat untuk membebaskan dirinya dengan meraih kesadaran. Sama halnya, objektivitas-objektivitas yang terkandung dalam apa yang diwariskan tergantung sepenuhnya kepada akal untuk dibawa kepada pemahaman, yaitu diperkenalkan kembali kepada ranah pemahaman melalui proses penafsiran. ${ }^{13}$

\section{Norma Dalam Objek Penafsiran}

Jadi, dalam pandangan Betti, sekalipun penafsiran bisa sampai kepada objektiftas, namun objektiftas penafsiran tersebut tetap relatif. Bagi Betti, makna seharusnya diderivasi dari teks dan bukan dimasukkan ke dalam teks. (meaning has to be derived from the text and not imputed to it). Untuk meraih penafsiran objektif, Betti menyusun empat norma. Dua norma terkait dengan objek penafsiran dan dua norma lain terkait dengan subjek penafsiran. Dua norma yang terkait dengan objek penafsiran menunjukkan objek pemahaman merupakan makna

\footnotetext{
12 Ibid, 32.

${ }^{13} \mathrm{Ibid}, 36$.
}

Ulul Albab: Jurnal Studi dan Penelitian Hukum Islam 
yang dimaksudkan oleh pengarang serta koherensi internalnya. Kedua norma tersebut sebagai berikut:

Pertama, norma otonomi objek hermeneutis dan standar hermeneutis yang immanent (the canon of the hermeneutical autonomy of the object and immanence of the hermeneutical standart). Dengan norma ini, Emilio Betti ingin menyatakan bahwa makna harus didasarkan kepada objek penafsiran, yaitu bentuk-bentuk yang penuh makna yang harus dianggap sebagai otonomi. Makna yang ditafsirkan adalah makna yang immanent, bukan proyeksi penafsir. Maksudnya, bentuk-bentuk yang penuh makna harus dianggap sebagai otonomi. Otonomi objek penafsiran harus dimengerti dengan kesesuaiannya dengan perkembangan logikanya sendiri. Bentuk-bentuk yang penuh makna harus dinilai dalam kaitannya dengan standart-standart yang immanent dalam keinginan asli pengarangnya. Norma "mens dicentis" ini dalam pemahaman hermeneutis, verstehen, mengikuti pola penafsiran bahwa "sensus non est inferendus sed efferendus"

Kedua, norma koherensi makna (prinsip totalitas) (the canon of the coherence of meaning (principle of totality). Dengan norma ini, Emilio Betti memaksudkan bahwa keseluruhan dan sebagian dalam bentuk-bentuk yang penuh makna saling berhubungan. Makna keseluruhan harus berasal dari unsurunsur individu. Sama halnya, sebuah unsur individu harus dimengerti dengan merujuk kepada keseluruhan yang komprehensif dimana unsur individu tadi merupakan bagiannya. ${ }^{14}$

\section{Norma Dalam Subjek Penafsiran.}

Pertama, norma aktualitas pemahaman (The canon of the actuality of understanding). Dengan norma ini Emilio Betti

14 Abd Hadi, "Hermeneutika Qurani dan Perbedaan Pemahaman dalam Menafsirkan al-Quran", dalam Islamica: Jurnal Studi Keislaman, Vol. 6, No. 1, September 2011, (Surabaya: Program Pascasarjana IAIN Sunan Ampel, 2011), 4. 
$154 \mid$ Labib Fahmi

menginginkan bahwa tugas penafsir adalah untuk menelusuri kembali proses kreatif, membangun kembali proses tersebut dalam dirinya, menerjemahkan kembali pemikiran Yang Lain, bagian dari masa lalu, peristiwa yang telah dadiingat, ke dalam akutalitas kehidupannya sendiri. Maksudnya, merekonstruksi dan mengintegrasikannya ke dalam wawasan intelektual seseorang dalam framework pengalamannya sendiri dengan melalui sejenis transformasi dengan didasarkan kepada sintesis yang sejenis yang memungkinkan rekognisi dan rekonstruksi dari pikiran tersebut. Tugas penafsir adalah menemukan makna yang dimaksud pengarang. Bagaimanapun, ini tidak menunjukkan penafsir adalah penerima yang pasif tetapi rekonstruktif secara aktif. Selain itu, kondisi subjek penafsir tidak tepat untuk disamakan dengan gagasan Gadamer 'Vorverständnis' (pra-pemahaman). ${ }^{15}$

Kedua, norma keharmonisan makna hermeneutis (kemantapan-makna dalam pemahaman). Menurut norma ini, penafsir seharusnya berusaha membawa aktualitas kehidupannya sendiri ke dalam harmoni yang paling erat dengan stimulasi yang ia terima dari objek sehingga satu dan yang lain meresonansikan dengan cara yang harmoni. Norma ini mensyaratkan penerjemah harus membawa subjektiftasnya ke dalam harmoni dengan stimulasi-stimulasi objeknya. Betti mengakui fakta bahwa penerjemah bisa memahami pokok persoalan dalam pengalamannya sendiri, tetapi dia harus membuat selalu berusaha untuk mengkontrol 'prejudisprejudis'nya dan mensubordinasikan pengetahuannya ke dalam objek makna yang disampaikan di dalam teks.

Jadi, empat norma yang menjadi petunjuk penafsir dalam menghasilkan makna orisinal secara objektif sebagaimana yang dikehendaki penulis atau pengarang dapat digambarkan sebagai

${ }^{15}$ W. Poespoprojo, Hermeneutika, (Bandung: Pustaka Setia, 2004), 14.

Ulul Albab: Jurnal Studi dan Penelitian Hukum Islam 
berikut: ${ }^{16}$

Norma Otonomi Hermeneutika Objek

Prinsip Kemutlakan/Prinsip Koherensi

Makna

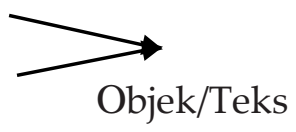

Norma Aktualisasi Pemahaman

Norma Keharmonisan

\section{Proses Triadik dalam Hermeneutika Betti}

Di antara para flsuf hermeneutika, memang Betti inilah yang paling banyak sumbangsihnya berkenan dengan aplikasi hermenutik untuk penelitian. Menurut Betti, setiap aktivitas penafsiran adalah triadic process, yakni proses tiga segi. Proses triadik bisa digambarkan sebagai berikut: ${ }^{17}$

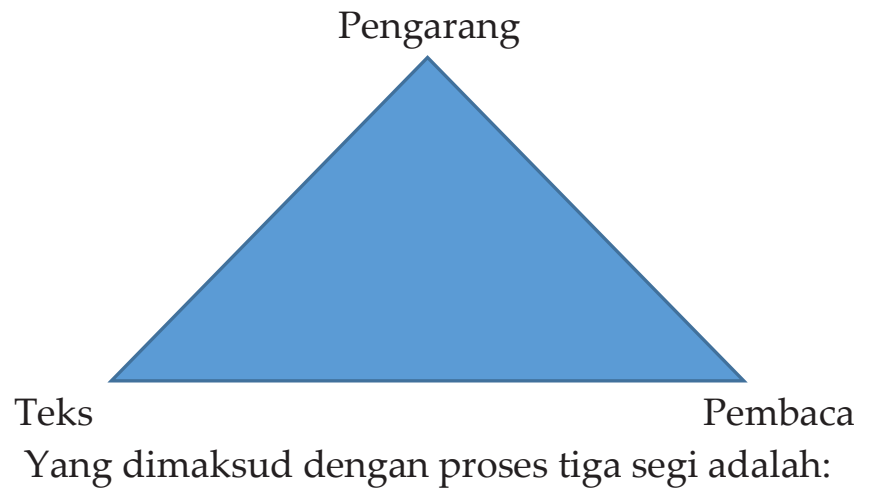

A. Objek yang ditafsirkan; yakni the mind objectivated in the meaning-full forms atau the mind of the other. Istilah the mind objectivated in the meaning-full forms berarti pemikiran yang diobjektifkan (pemikiran yang dilepas masuk ke ruang objektif) sehingga pemikiran itu tidak lagi disimpan dalam ruang subjektif.

B. Subjek yang menafsirkan atau an active thinking mind.

${ }^{16}$ Ilyas Supena, Bersahabat dengan Makna Melalui Hermeneutika, (UIN Walisongo Semarang, 2012), 56.

17 T.M. Seebohm, Hermeneutics, Method and Methodology, (USA: Kluwer Academic Publisher, 2004), 11. 
$156 \mid$ Labib Fahmi

C. The meaning-full forms sebagai medium atau perantara yang menghubungkan subjek dengan objek. The meaningfull forms sebagai medium haruslah dibedakan dari the mind objectivated in the meaning-full forms yang menjadi objek kajian.

Plato menggunakan "forms" identik dengan idea dan general concept. Bleicher menjelaskan istilah forms dalam pengertian yang luas sebagai struktur yang homogin karena di dalamnya memuat sejumlah unsur yang memiliki relasi satu dengan lainnya serta konteks dengan ide dan gagasan pihak lain. ${ }^{18}$

Objectivation of mind dalam teori proses tiga segi, istilah objectivation of mind berarti the mind of the others. Konsep ini menunjuk kepada pemikiran atau gagasan orang lain yang menjadi objek kajian Betti memberi perhatian mengenai hubungan antara kemampuan bahasa dan masyarakat penutur (the community of speakers). Masyarakat penutur adalah entitas supra individual yang memiliki karakter transendental, maksudnya, yakni peluang kevalidan makna produk entitas supra individual ini mencapai tingkat kualitatif dibanding dari produk perorangan Meaningful forms dari entitas supra indivual ini juga bertindak sebagai pra kondisi proses penafsiran.

Betti membedakan antara analisis normatif-aksiologis dari analisis fenomenologis. Dalam analisis normatif aksiologis, diperlukan kriteria tertentu sebagai standard untuk penilaian. Standard penilaian tidak harus bersumber dari pembuktian empirik, tetapi juga dari keautentikan proposisi. Artinya, sauatu proposisi atau beberapa proposisi itu diterima secara sadar dan dihayati sebagai tata nilai yang dihayati karena ia diyakini memberi arah, tujuan dan bimbingan hidup yang bermanfaat. Penilaian ini tergantung kepada para warga atau anggota yang terlibat dalam proses penghayatan dalam sebuah komunitas

${ }^{18}$ Josef Bleicher, Hermeneutika Kontemporer ....., 54.

Ulul Albab: Jurnal Studi dan Penelitian Hukum Islam 
tertentu. ${ }^{19}$

\section{Jenis-Jenis dan Momen Interpretasi}

Betti memperhatikan "empat momen teoritis" dalam proses interpretasi yang masing-masing merepresentasikan bentuk-bentuk penerimaan dan pendekatan intelektual yang berbeda dan yang berselang-seling dalam proses ini. ${ }^{20}$ Empat momen penafsiran menurut Betti yaitu:

a) Momenflologi

Secara umum, momen ini digunakan untuk memahami simbol-simbol yang baku yang permanen; memahami koherensi logik dan konsistensi logik dari suatu teks atau wacana lisan. Momen flologi berkepentingan untuk rekonstruksi makna dan upaya menjelaskan makna yang berada di balik fakta. Misal, ada fakta lampu merah di persimpangan jalan. Fakta ini menyembunyikan makna tertentu, khususnya, bagi pengguna jalan.

b) Momenkritik

Momen kritik dipergunakan pada kasus yang di dalam dirinya mengundang tanda tanya seperti munculnya ungkapan suatu sikap yang tidak rasional dan tidak konsisten.

c) Momenpsikologi

Momen ini berlaku ketika penafsir berhadapan dengan kondisi yang mengharuskn dia menyelami jiwa seseorang yang melakukan suatu tindak tertentu. Penafsir menyelami jiwa orang-orang yang terkena musibah lumpur yang nasibnya terkatung-katung meskipun mereka sudah sekian lama mengalami musibah tersebut. Lalu mereka melakukan demo besar- besaran dan menimbulkan gangguan lalu lintas. Penafsir, dalam hal menghadapi kondisi semacam ini, dia seolah-olah menjadi mereka, dia memasuki jiwa mereka sehingga tidak terlalu mempersalahkan demo mereka yang menimbulkan

\footnotetext{
${ }^{19}$ Ibid., 53.

${ }^{20}$ Ibid., 51.
} 
$158 \mid$ Labib Fahmi

gangguan jalan.

d) Momen Teknik Morfologi

Momen ini bertujuan memahami makna yang terkandung dalam sikap mental tertentu kaitannya dengan prinsip-prinsip yang berlaku. Betti, memberikan misal kehidupan sebuah komunitas tertentu yang berada di bawah seorang tokoh. Ajaran-ajaran yang mengikat mereka disampaikan secara lisan. Jika seorang tokoh menyampaikan instruksi agar mereka berpuasa pada hari ini atau hari itu, mereka mengikuti perintah tersebut.

\section{Surat An-Nisa Ayat 11 dan Sebab-Sebab Turunnya Wahyu}

Surat An-Nisa ayat 11 adalah sebagai berikut:

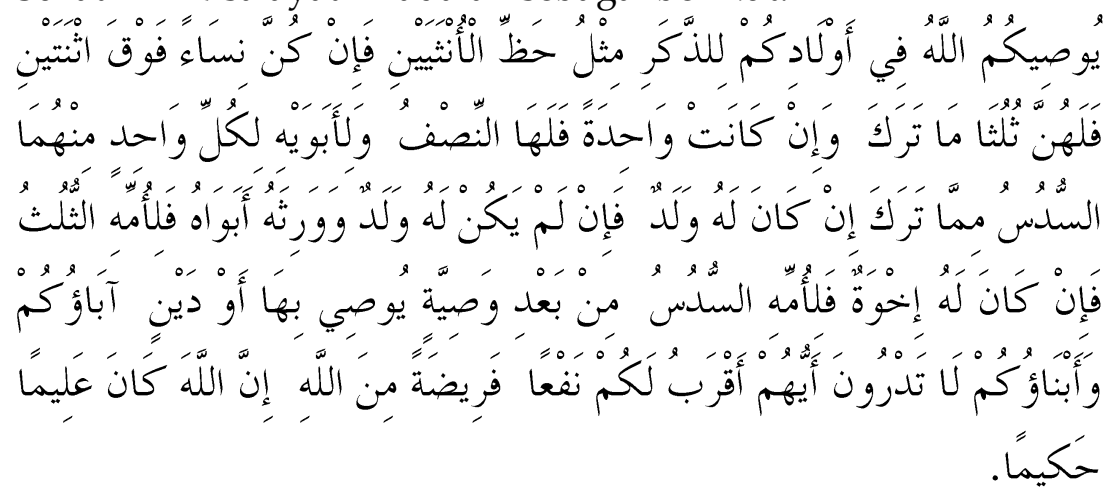

Artinya:

"Allah mensyari'atkan bagimu tentang (pembagian pusaka untuk) anak-anakmu. Yaitu: bahagian seorang anak lelaki sama dengan bagahian dua orang anak perempuan; dan jika anak itu semuanya perempuan lebih dari dua, maka bagi mereka dua pertiga dari harta yang ditinggalkan; jika anak perempuan itu seorang saja, maka ia memperoleh separo harta. Dan untuk dua orang ibu-bapa, bagi masingmasingnya seperenam dari harta yang ditinggalkan, jika yang meninggal itu mempunyai anak; jika orang yang meninggal tidak mempunyai anak dan ia diwarisi oleh ibu-bapanya (saja), maka ibunya mendapat sepertiga; jika yang meninggal itu mempunyai beberapa

Ulul Albab: Jurnal Studi dan Penelitian Hukum Islam 
saudara, maka ibunya mendapat seperenam. (Pembagian-pembagian tersebut di atas) sesudah dipenuhi wasiat yang ia buat atau (dan) sesudah dibayar hutangnya. (Tentang) orang tuamu dan anakanakmu, kamu tidak mengetahui siapa di antara mereka yang lebih dekat (banyak) manfaatnya bagimu. Ini adalah ketetapan dari Allah. Sesungguhnya Allah Maha Mengetahui lagi Maha Bijaksana".

Qamaruddin Shaleh dalam bukunya Asbabun Nuzul Latar belakang Historis Turunya Ayat-Ayat al-Quran (1995) mulai menafsirkan surat an-nisa ini dengan menyebutkan bahwa turunya surat berkaitan dengan kebiasaan-kebiasaan masyarakat Arab Jahiliyah dan masyarakat Arab setelah datangnya Nabi Muhammad s.a.w, dalam buku tersebut didahului dengan ungkapan riwayat bahwa biasanya kaum bapak menerima dan menggunakan maskawin tanpa seijin putrinya, maka diturunkanlah ayat ke empat surat an-nisa, kemudian dilanjutkan membahas surt ke tujuh yaitu dengan riwayat bahwa kondisi masyarakat jahiliyah mempunyai hukum yang dijadikan adat kebiasaan bahwa kaum jahiliyah tidak membarikan harta peninggalan warisan kepada anak lakilaki yang belum dewasa dan kepada anak wanita. ${ }^{21}$

Diriwayatkan ketika seorang sahabat dari golongan Anshor yang bernama Aus bin Tsabit meninggal dunia dan meninggalkan dua orang putri serta satu orang anak laki laki yang masih kecil, datanglah dua orang anak pamanya yaitu Khalid dan Arfathah (dalam posisi sebagai asobah) mengambil semua harta peninggalan Aus bin Tsabit, Istri almarhum Aus bin Tsabit pun mendatangi Rasulullah s.a.w untuk menjelaskan kejadian tersbut, Rasulullah s.a.w. pun bersabda: saya tidak tahu apa yang harus saya katakana, maka turunlah ayat ke 7 sebagai penjelassan hukum pembagian harta pusaka dalam Islam. ${ }^{22}$

${ }^{21}$ Qamaruddin Shaleh, Asbabun Nuzul Latar Belakang Historis Turunya Ayat-Ayat al-Quran, (Bandung: CV Diponegoro 1995), 122.

${ }^{22}$ Ibid., 123. 
$160 \mid$ Labib Fahmi

Diriwayatkan oleh Imam yang enam, yang bersumber dari Jabir bin 'Abdillah bahwa Rasulullah saw. disertai Abu Bakr berjalan kaki menengok Jabir bin 'Abdillah sewaktu sakit keras di kampung bani Salamah. Ketika didapatkannya tidak sadarkan diri, beliau minta air untuk berwudlu dan memercikan air padanya, sehingga sadar. Lalu berkata Jabir: "Apa yang tuan perintahkan kepadaku tentang harta bendaku?" maka turunlah ayat tersebut di atas (an-Nisaa': 11-12) sebagai pedoman pembagian harta waris.

Diriwayatkan oleh Ahmad, Abu Dawud, at-Tirmidzi, dan al-Hakim, yang bersumber dari Jabir, bahwa istri Sa'd bin ar-Rabi' menghadap Rasulullah saw. dan berkata: "Ya Rasulallah. Kedua putri ini anak Sa'd bin ar-Rabi' yang menyertai tuan dalam perang Uhud dan ia telah gugur sebagai syahid. Paman kedua anak ini mengambil harta bendanya, dan tidak meninggalkan sedikitpun, sedang kedua anak ini sukar mendapatkan jodoh kalau tidak berharta." Rasulullah saw. bersabda: "Allah akan memutuskan persoalan tersebut." Maka turunlah ayat hukum pembagian waris seperti tersebut di atas. (an-Nisaa': 11-12) ${ }^{23}$

Keterangan: menurut al-Hafidz Ibnu Hajar, berdasarkan hadits tentang kedua putri Sa'd bin ar-Rabi', ayat ini (an-Nisaa': 11-12) turun berkenaan dengan kedua putri itu dan tidak berkenaan dengan Jabir, karena Jabir waktu itu belum mempunyai anak. Selanjutnya ia menerangkan bahwa ayat ini (an-Nisaa': 11-12) turun berkenaan dengan keduanya. Mungkin ayat 11 pertama berkenaan dengan kedua putri Sa'd dan bagian akhir ayat itu, yaitu (an-Nisaa': 12) berkenaan dengan kisah Jabir. Adapun maksud Jabir dengan kata-katanya, "turun ayat 11 ", ingin menyebutkan hal penetapan hukum waris bagi

${ }^{23}$ At-Tirmidzî juga meriwayatkan sebagaimana Hadis di atas dalam al-Jâmi' ash-Shahîh Sunan at-Tirmidzînya (3/179 dan 4/86),

Ulul Albab: Jurnal Studi dan Penelitian Hukum Islam 
kalaalah (orang yang tidak meninggalkan anak dan ayah), yang terdapat pada ayat selanjutnya.

Diriwayatkan oleh Ibnu Jarir yang bersumber dari asSuddi bahwa orang Jahiliyah tidak meberikan harta waris kepada wanita dan anak laki-laki yang belum dewasa atau yang belum mampu berperang. Ketika 'Abdurrahman (saudara Hassan bin Tsabit, ahli syair yang masyur) wafat, ia meninggalkan seorang istri bernama Ummu Kuhhah dan lima orang putri. Maka datanglah keluarga suaminya mengambil harta bendanya. Berkatalah Ummu Kuhhah kepada Nabi saw. mengadukan halnya. Maka turunlah ayat tersebut di atas (anNisaa': 11) yang menegaskan hak waris bagi anak-anak wanita dan ayat (an-Nisaa': 12) yang menegaskan hak waris bagi istri. ${ }^{24}$

Diriwayatkan oleh al-Qadli Isma'il di dalam kitab Ahkaamul Qr'aan, yang bersumber dari 'Abdul Malik bin Muhammad bin Hazm bahwa peristiwa Sa'd bin ar-Rabi' berkaitan dengan turunnya surah an-Nisaa' ayat 127. 'Amrah binti Hazm yang ditinggal gugur oleh suaminya (Sa'd bin arRabi', sebagai syahid di perang Uhud, menghadap Nabi saw. dengan membawa putrinya (dari Sa'd bin ar-Rabi') menuntut hak waris. Surah an-Nisaa' ayat 127 tersebut menegaskan kedudukan dan hak wanita dalam hukum waris. ${ }^{25}$

Imam Bukhori berkata: Ibrâhîm bin Mûsâ telah bercerita kepada saya (Bukhârî), katanya (Ibrâhîm bin Mûsâ): “Hisyâm telah mengabarkan kepada kami (Ibrâhîm bin Mûsâ) bahwa Ibnu Juraij mengatakan: "Ibnu al-Munkadir telah mengabarkan kepada saya (Ibnu Juraij) dari Jâbir bin 'Abdullâh, katanya (Jâbir bin 'Abdullâh): "Nabi SAW. dan Abû Bakar ash-Shiddîq membesukku (mengunjungi/menjenguk Jâbir bin 'Abdullâh) di kampung Bani Salimah dengan berjalan kaki. Dan Nabi SAW.

24 ". Ibnu Jarîr juga mengeluarkan sebagaimana Hadis di atas dalam Jâmi' al-Bayâni fî at-Ta'wîl al-Qurâninya (14/276).

${ }^{25} \mathrm{Ibnu}$ al-Jarûd juga mengeluarkan sebagaimana Hadis di atas dalam Muntaqâ Ibn al-Jarûdnya (hlm. 319). 
$162 \mid$ Labib Fahmi

Melihatku (Jâbir bin 'Abdullâh) dengan tidak sadar (karena kecapekan/keletihan berjalan kaki), lalu beliau (Nabi SAW.) minta air wudhu lalu berwudhu kemudian memercikkan air kepadaku (Jâbir bin 'Abdullâh), aku (Jâbir bin 'Abdullâh) pun sadar. Aku (Jâbir bin 'Abdullâh) berkata: “Apa yang anda (Nabi SAW.) perintahkan kepadaku tentang hartaku, wahai Rasûlullâh?". Maka turunlah ayat ini. ${ }^{26}$

Demikian juga Imâm Jalâluddîn as-Suyûthî yang berkata tentang penafsiran surat an-nisa ayat 11 ini. ${ }^{27}$.

Dikemukakan oleh Ahmad bin Hanbal, Abû Dâwûd, atTirmidzî dan al-Hâkim yang bersumber dari Jâbir bin 'Abdullâh. Jâbir bin 'Abdullâh berkata: "Isteri Sa'îd bin ar-Râbi' menghadap Rasûlullâh SAW. lalu (Isteri Sa'îd bin ar-Râbi') berkata: "Wahai Rasûlullâh SAW; kedua puteri saya (Isteri Sa'îd bin ar-Râbi') ini adalah puteri Sa'îd bin ar-Râbi' yang telah gugur sewaktu bersama engkau (Nabi SAW) di perang Uhud. Dan sesungguhnya paman kedua puteri ini mengambil harta bendanya (harta benda Sa'îd bin ar-Râbi') dan tidak sedikitpun ditinggalkannya harta, sedangkan mereka (kedua puteri Sa'îd bin ar-Râbi') sulit menikah kecuali mereka (kedua puteri Sa'îd bin ar-Râbi') mempunyai harta benda". Maka beliau SAW. bersabda: "Allah SWT. akan memberi keputusan hukum perkara tersebut". Maka turunlah ayat. ${ }^{28}$

Ibnu Majah ${ }^{29}$ juga meriwayatkan:

"Kemudian Rasulullah SAW datang kepada paman mereka (paman kedua puteri Sa'îd bin ar-Râbi') seraya (Nabi SAW.) bersabda: "Berikan untuk kedua puteri Sa'îd bin ar-Râbi'

${ }^{26}$ Imam Bukhori, jilid 1 hal 313. 12 hal 218.

${ }^{27}$ Imâm Jalâluddîn as-Suyûthî juga mengeluarkan sebagaimana Hadis di atas dalam Lubâb an-Nuqûli fì Asbâb an-Nuzûlinya (Juz. 4, 4/an-Nisâ').

28 Imâm Ahmad bin Hanbal dalam Musnad al-Imâm Ahmad Ibn Hanbalnya (3/352).

${ }^{29}$ Ibnu Mâjah juga meriwayatkan sebagaimana Hadis di atas dalam Sunan Ibn Mâjahnya (2720).

Ulul Albab: Jurnal Studi dan Penelitian Hukum Islam 
2/3 (dari harta warisan ayah mereka), (dan berikan) ibunya (isteri Sa'îd bin ar-Râbi') 1/8, dan sisanya untuk kamu (paman kedua puteri Sa'îd bin ar-Râbi')" ${ }^{30}$

Beberapa kitab tafsir menjelaskan seperti dalam tafsir jalalain: (Allah mewasiatkan atau menitahkan padamu mengenai anak-anakmu) dengan apa yang akan disebutkan ini: (yaitu bagian seorang anak lelaki sama dengan bagian dua orang anak perempuan) di antara mereka.

Tafsir Qurais Syihab: Allah memerintahkan kalian, dalam urusan warisan anak-anak dan kedua orangtua kalian bila kalian meninggal dunia, untuk melakukan sesuatu yang bisa mewujudkan keadilan dan perbaikan. Apabila anak yang ditinggalkan terdiri atas laki-laki dan perempuan, maka bagian seorang anak laki-laki dua kali bagian anak perempuan

Tafsir Ibnu Kasir: Ayat yang mulia ini serta ayat-ayat sesudahnya dan ayat penutup surat ini adalah ayat-ayat mengenai ilmu faraidh (pembagian warisan). Dan ilmu faraidh tersebut diistimbatkan (diambil sebagai suatu kesimpulan hukum"Ed) dari tiga ayat ini dan hadits-hadits yang menjelaskan hal tersebut sebagai tafsirnya. Sebagian dari apa yang berkaitan dengan tafsir masalah ini akan kami sebutkan. Sedangkan berkenaan dengan keputusan masalah, uraian perbedaan pendapat dan dalil-dalilnya serta hujjah-hujjah yang dikemukakan oleh para imam, tempatnya adalah dalam kitabkitab hukum. Hanya kepada Allah tempat meminta pertolongan. ${ }^{31}$

Sesungguhnya telah datang anjuran mempelajari ilmu fara-idh, dan pembagian-pembagian tertentu ini merupakan hal yang terpenting dalam ilmu itu. Terdapat hadits yang diriwayatkan oleh Abu Daud dan Ibnu Majah, dari Abdullah bin

${ }^{30} \mathrm{Ibnu}$ Sa'd juga mengeluarkan sebagaimana Hadis di atas dalam athThabaqât al-Kubrânya (Volume: 3, bagian: 2, hal. 78).

${ }^{31}$ Ibnu Katsir, Tafsir al-Quran al-Adzim, Kairo, Maktabah as-Shofa, 2002:134. 
$164 \mid$ Labib Fahmi

'Amr secara marfu': "Ilmu itu ada tiga, sedangkan selainnya adalah keutamaan (pelengkap); Ayat yang muhkam, sunnah yang pasti atau fara-idh yang adil." Ibnu 'Uyainah berkata: "Fara-idh disebut sebagai setengah ilmu, karena semua manusia diuji olehnya."

Ketika menafsirkan ayat ini, al-Bukhari meriwayatkan dari Jabir bin 'Abdillah, ia berkata: "Rasulullah dan Abu Bakar yang sedang berada di Bani Salam menjengukku dengan berjalan kaki. Lalu, beliau menemukanku dalam keadaan tidak sadarkan diri. Maka beliau meminta air untuk berwudhu dan mencipratkannya kepadaku, hingga aku sadar. Aku bertanya: "Apa yang engkau perintahkan untuk mengelola hartaku ya Rasulullah?" Maka turunlah ayat: yuushiikumullaaHu fii aulaadikum lidz-dzakari mitslu hadh-dhil untsayain ("Allah mensyariatkan kepadamu tentang [pembagian waris untuk] anak-anakmu. Yaitu, bagian seorang anak laki-laki sama dengan bagian dua orang anak perempuan.") Demikianlah yang diriwayatkan oleh Muslim, an-Nasa'i dan seluruh jama'ah.

Firman Allah: yuushiikumullaaHu fii aulaadikum lidz-dzakari mitslu hadh-dhil untsayain ("Allah mensyariatkan kepadamu tentang [pembagian waris untuk] anak-anakmu. Yaitu, bagian seorang anak laki-laki sama dengan bagian dua orang anak perempuan.") Artinya, Dia memerintahkan kalian untuk berbuat adil kepada mereka. Karena, dahulu orang-orang Jahiliyyah memberikan seluruh harta warisan hanya untuk lakilaki, tidak untuk wanita. Maka, Allah swt. memerintahkan kesamaan di antara mereka dalam asal hukum waris dan membedakan bagian di antara dua jenis tersebut, di mana bagian laki-laki sama dengan dua bagian perempuan. Hal itu disebabkan karena laki-laki membutuhkan pemenuhan tanggung jawab nafkah, kebutuhan, serta beban perdagangan, usaha dan resiko tanggung jawab, maka sesuai sekali jika ia 
diberikan dua kali lipat daripada yang diberikan kepada wanita. ${ }^{32}$

Sebagian pemikir mengambil istimbath dari firman Allah Ta'ala ini, "Allah mensyariatkan bagimu tentang (pembagian waris untuk) anak-anakmu. Yaitu, bagian seorang anak laki-laki sama dengan bagian dua orang anak perempuan." Bahwa Allah lebih sayang kepada makhluk-Nya daripada seorang ibu kepada anaknya. Di mana Allah mewasiatkan kepada kedua orang tua tentang anak-anak mereka. Maka dapatlah diketahui bahwa Allah lebih sayang kepada mereka daripada mereka sendiri.

Di dalam hadits shahih dijelaskan bahwa beliau pernah melihat seorang tawanan wanita yang dipisahkan dari anaknya. Maka ia berkeliling mencari-cari anaknya. Tatkala ia menemukannya dari salah seorang tawanan. Ia pun mengambilnya, mendekapnya dan menyusukannya, maka Rasulullah bertanya kepada para Sahabatnya: “Apakah kalian berpendapat bahwa wanita ini tega akan membuang anaknya ke dalam api dan ia pun mampu melakukan hal itu?" Mereka menjawab: “Tidak ya Rasulullah!" Beliau bersabda: “Demi Allah, sesungguhnya Allah lebih penyayang kepada hambahamba-Nya dari pada wanita ini kepada anaknya."

Dalam masalah ini, al-Bukhari meriwayatkan dari Ibnu 'Abbas, ia berkata: "Dahulu, harta itu untuk anak, sedangkan wasiat untuk kedua orangtua, maka Allah menghapuskan hal tersebut apa yang lebih dicintai-Nya, lalu dijadikan bagian lakilaki sama dengan dua bagian perempuan, menjadikan setiap satu dari orang tua $1 / 6$ atau $1 / 3$, untuk isteri $1 / 8$ atau $1 / 4$ dan untuk suami $1 / 2$ atau $1 / 4 . "$

Firman-Nya, fa in kunna nisaa-an fauqats-nataini falaHunna tsulutsaa maa taraka ("Dan jika anak itu semuanya perempuan lebih dari dua, maka bagi mereka dua pertiga dari harta yang

${ }^{32}$ Ibnu Katsir, Tafsir al-Quran al-Adzim, Kairo, Maktabah as-Shofa, 2002:135. 
$166 \mid$ Labib Fahmi

ditinggalkan.") Diperolehnya bagian dua anak perempuan dua pertiga adalah diambil dari hukum bagian dua saudari perempuan dalam ayat terakhir (dua dari surat an-Nisaa' ini, Ed), karena di dalamnya Allah menetapkan saudari perempuan dengan dua pertiga. Apabila dua orang saudari perempuan mendapatkan dua pertiga, maka memberikan waris dua pertiga kepada anak perempuan jelas lebih utama. Sebagaimana pada penjelasan yang lalu di dalam hadits Jabir bahwa Rasulullah menetapkan dua pertiga untuk dua orang puteri Sa'ad bin Rabi'. Al-Qur'an dan as-Sunnah menunjukkan hal tersebut. ${ }^{33}$

\section{Hermeunetika Emillio Betti Diaplikasikan Dalam Menafsirkan Surat An-Nisa Ayat 11 Tentang Pembaigan Waris 2:1 Untuk Laki-Laki Dan Perempuan}

Bagi Emilio Betti, makna itu sebagaimana yang dimaksudkan oleh pengarang dan agen-agen historis dirujuk kepada bentuk-bentuk yang penuh makna yang merupakan objektifkasi pemikiran manusia. Bagi Emilio Betti, terutamanya melalui bentuk-bentuk bahasa yang objektif dan struktur tingkah laku subjek yang menafsirkan menemukan akal yang lain. Bagi Emilio Betti, hermeneutika adalah metode yang diaplikasikan kepada penafsiran dalam menjamin objektiftas hasilnya. Dengan menggunakan metode yang benar serta norma penafsiran yang benar, seorang penafsir mampu untuk meraih di luar kondisi historisnya untuk memahami makna sebuah teks sebagaimana yang dimaksudkan oleh pengarang. Aturan-aturan dan norma-norma yang mengarahkan penafsiran dapat diaplikasikan secara universal kepada teks apapun.

Makna surat an-nisa ayat 11 yang menjelaskan sistem waris dua banding satu untuk laki laki dan perempuan adalah benar dilihat dari penafsiran manapun, baik secara filologi

${ }^{33}$ Ibnu Katsir, Tafsir al-Quran al-Adzim, Kairo, Maktabah as-Shofa, 2002:134.

Ulul Albab: Jurnal Studi dan Penelitian Hukum Islam 
maupun secara histori, bahwa secara realitas, Nabi Muhammad tidak menafsirkan ulang ketika turunya wahyu tersebut, Nabi mengatakan: apa yang harus aku lakukan?, kalimat tersebut merupakan tanggapan serius terhadap fenomena sistem waris yang sudah ada dan berjalan pada masa tersebut.

Para sahabat yang mengadukan pada dasarnya adalah menanyakan sistem atau model pembagian waris ddalam ajaran Islam sendiri yang sumbernya ketika itu langsung kepada Nabi Muhammad juga ketika Nabi masih hidup. Dalam kerangka ini, para sahabat bertanya dipastikan ada latar belakang yang menjadikan mereka bertanya atau tepatnya "mengadu" kepada Nabi Muhammad, menurut standar Bahasa yang digunakan dalam hadis, para sahabat -prasangka penulis- mulai meragukan sistem yang digunakan masyarakat jahiliyah yang seakan akan tidak adil terhadap para wanita, khususnya dalam kasus yang menimpa sahabat tersebut.

Ketidakadilan ini di-adu-kan kepada Nabi Muhammad dengan bertanya dan menceritakan kejadian yang sebenarnya, bilia dilihat dalam perpektif momenflologi Emillio Betti dimana momen ini digunakan untuk memahami simbol-simbol yang baku yang permanen; memahami koherensi logik dan konsistensi logik dari suatu teks atau wacana lisan. Momen flologi berkepentingan untuk rekonstruksi makna dan upaya menjelaskan makna yang berada di balik fakta. Ada fakta tentang ketidak adilan pembagian waris model jahiliyah, ada fakta Nabi Muhammad tidak dapat memutuskan bila menggunakan model pembagian sistem Jahiliyah.

Setelah kedua fakta tersebut ternyata ada fakta yang solutatif memberikan solusi berdasarkan peristiwa yang terjadi, yaitu fakta turunya wahyu yang menjelaskan model pembagian waris yang diwasiatkan atau diperintahkan oleh Allah.

Ada hal yang menarik ketika Nabi menjawab dengan: apa yang harus aku perbuat?, dalam hal ini secara psikologis Nabi Muhammad (secara psikologis) merasa bahwa apa yang 
$168 \mid$ Labib Fahmi

dirasakan oleh para sahabat juga dirasakan oleh Nabi sendiri, dan Nabi membutuhkan solusi yang tepat untuk menangani permasalahan yang diadukan, dengan begitu, menurut perpektif Momenpsikologi Emillio Betti, Nabi Muhammad sangat faham terhadap masalah yang diadukan dan sangat memahai kondisi psikologi para sahabatnya.

Menurut hemat penulis, tanggapan psikologi Nabi Muhammad ini sebenanrya merupakan kritik terhadap sistem jahiliyah yang sangat terasa kurang adil, bagaimana mungkin bila seseorang meninggal dunia dan meninggalkan harta beserta anak anak yang (hanya) kebetulan perempuan, lantas anak perempuan tersebut tidak mendapatkan hak kewarisan. Mungkin ini dikritik oleh Nabi sendiri, sama sama keturunan sang mayit, sama sama berkedudukan anak, sama sama mempunyai kebutuhan-kebutuhan materiil. hanya berbeda jenis kelamin saja bisa menghilangkan hak yang sama dengan hak hak anak laki-laki.

Nabi juga -mungkin- mengkritik mengapa anak laki-laki yang belum dewasa juga kehilangan hak waris, dan kedudukan anak perempuan disamakan dengan kedudukan anak yang belum dewasa tersebut, bagi penulis ini merupakan momenkritik Nabi terhadap fenomena masyarakat jahiliyah yang sudah berjalan dan berlangsung lama.

Nabi merupakan tokoh sentral dalam peristiwa ini, sehingga para sahabat mengadukan kepada Nabi yang -pastiakan diikuti juga apa yang akan diperintahkan oleh Nabi. Begitupun para penafsir-penafsir sesudahnya hingga sampai sekarang, akan selalu mendasarkan pendapat tafsirnya kepada apa yang pernah Nabi Muhammad sampaikan pada masa itu. Dalam perspektif momen teknik morfologi yang dianut Bertti, ini pasti akan dilakukan oleh para penganut agama Islam, sebab Nabi Umat Islam melakukan, maka itu yang mereka tafsirkan dan lakukan, pertanyaanya adalah apakah obyektif, menurut

Ulul Albab: Jurnal Studi dan Penelitian Hukum Islam 
model ini, jelas ini obyektif, sebab standar Nabi menjawab problem tersebut juga obyektif.

Bagaimana dengan maksud tersembunyi dari surat annisa ayat 11 kaitanya dengan fenomena tersebut, ini yang akan penulis uraikan berdasarkan perspektif Betti bahwa penafsiran terhadap teks merupakan usaha untuk mengungkap apa yang ada sesungguhnya di balik teks tersebut. Bahwa benar solusi dari wahyu adalah dua banding satu untuk laki laki dan perempuan tidak dapat dinafikan dalam teks tersebut, bunyi teks tersebut mampu memberikan solusi dan jawaban yang bukan hanya ditunggu oleh Nabi Muhammad sendiri namun juga ditunggu oleh para sahabat dan sampai sekarang oleh Ummatnya.

Penulis akan menguraikan sebagai berikut:

Pertama, sistem kewarisan pada masa Nabi Muhammad dan sebelumnya menggunakan model sistem Patriarki, yaitu mengenal sistem waris yang menggunakan jalur laki-laki sebagai jalur yang diakui sah dan mempunyai kekuatan waris.

Kedua, sistem yang ditawarkan oleh Islam tidak sematamata turun kalau tidak ada peristiwa yang menjadi pangkal pokok masalah yang dirasakan oleh Nabi sendiri atau masyarakat pada waktu itu, artinya wahyu al-Quran turun sesuai kondisi fenomena dalam Bahasa arabnya hasbal waqo'iq.

Ketiga, sistem yang diperintahkan untuk membagi waris kepada anak laki-laki dan perempuan ketika itu adalah model yang paling baru dalam sejarah kebudayaan di Arab. Sebab arab yang menganut partriarkis tidak memberikan waris terhadap perempuan, dan al-Quran lah wahyu yang mengatur bahwa bukan sistem patriarki yang dikehendaki oleh Islam namun sistem yang adil, yaitu perempuan pun mempunyai hak waris terhadap harta warisan yang ditinggalkan.

Keempat, al-Quran hendak mengatakan bahwa tidak boleh menafikan perempuan sebagai ahliwaris, meskipun dalam memberikan jumlah prosentasi pembagian menggunakan model 
170| Labib Fahmi

dua banding satu, namun ada ide pertama yang sangat mendasar bahwa perempuan sama kedudukanya dengan laki laki sebagai ahli waris, adapun jumlah pembagian dua banding satu merupakan solusi yang bersifat tidak generalis. Perempuan berkedudukan menjadi ahli waris adalah satu generalis, sedangkan perbandingan pembagian merupakan aspek non generalis.

Di balik teks surat an-nisa ayat 11 ada maksud lain yang sangat besar yaitu meruntuhkan dominasi patriarki yang sangat tidak menguntungkan bagi perempuan maupun bagi laki laki maupun perempuan, dan ini akan menjadikan model keadilan yang baru dan dapat diterima oleh masyarakat luas.

Menurut teori yang dibangun oleh Hazairin, bahwa sistem waris dibangun di atas model sistem kekeluargaan, karena masyarakatnya adalah patrinial, maka sangat dapat dipastikan bahwa sistem waris yang digunakan adalah model waris bilateral, bila sistem masyarakatnya adalah matrinial, maka demikian juga dengan sistem waris yang digunakan, dan apabila sistem masyaraktnya mayorat, maka sistem kewarisan juga akan menjadi mayorat, ajaran Islam bukan begitu, agama Islam hendak menciptakan suatu sistem kekeluargaan yang baru yaitu tidak patrinial, tidak matrinial dan juga tidak mayorat, ajaran Islam yang khususnya termaktub dalam surat an-nisa ayat 11 hendak memproklamirkan bahwa Islam menginginkan masyarakat yang bilateral. Artinya semua mempunyai kedudukan yang sama di hadapan hokum, baik itu laki laki maupun perempuan khususnya dalam bidang hukum-hukum yang mengatur urusan privat semacam waris.

Jadi kalaupun ada pemikiran bahwa pembagian waris Islam yang mengacu pada pola dua banding satu berarti tidak dapat melihat fenomena historis bagaimana al-Quran dapat eksis dan diterima hingga sekarang, meskipun dapat juga muncul ide pembagian satu banding satu bagi laki-laki dan perempuan maka ide tersebut tidak dapat dinyatakan keluar 
dari ajaran Islam, sebab model pembagian dua banding satu merupakan aplikasi dari ide besar yaitu perempuan juga mempunyai kedudukan dalam hal kewarisan.

\section{Kesimpulan}

Retafsir atau kembali menafsirkan teks al-Quran dengan berbagai metode merupakan hal yang sangat lumrah, baik itu penafsiran pada masa lalu maupun metode penafsiran yang sedang berkembang pada masa sekarang, perkembangan pengetahuan menjadikan bahwa dalam memahami teks tidak dapat menafikan alat bantu yang sudah ada, namun dapat juga menggunakan alat bantu selain yang sudah mapan. Seperti halnya dalam surat an-nisa ayat 11 yang berisi tentang satu buah sistem waris yaitu model dua bagian untuk laki-laki dan satu bagian untuk perempuan tidak dapat ditafsirkan "saklek" itu saja, namun ada aspek historis dan aspek budaya yang melatarbelakangi mengapa ayat ini turun kepada Nabi Muhammad s.a.w.

Ajaran Islam tentang sebuah sistem keluarga dalam surat an-nisa ayat 11 tersebut ingin memproklamirkan sebuah sistem baru yaitu sistem kekeluargaan bilateral, tidak patrinial dan juga tidak matrinial, namun sistem di tengah tengah, tidak berat sebelah, anggapan bahwa model pembagian dua banding satu dalam sistem waris yang dinilai tidak adil sebenarnya karena pemahaman tidak diberlakukan secara komprehenship dan tidak obyektif.

\section{Daftar Pustaka}

Abî 'Abdillâh Muhammad bin Yazîd al-Qazwînî, Sunan Ibn Mâjah.

Ahmad, Imam. bin Hanbal Abû 'Abdullâh asy-Syaibânî. Musnad al-, Imâm Ahmad Ibn Hanbal

as-Suyûthî. Imâm Jalâluddîn. Lubâb an-Nuqûli fì Asbâb an-Nuzûli 
$172 \mid$ Labib Fahmi

Asy-Syaikh Muqbil bin Hadî al-Wadi'î. Ash-Shahîh al-Musnad min Asbâb an-Nuzûl.

at-Tirmidzî. Imam al-Hâfizh Abî 'Îsâ Muhammad bin 'Îsâ bin Saurah at-Tirmidzî, Al-Jâmi' ash-Shahîh Sunan at-Tirmidzî.

Bilen, Osman. 2000. The Historicity of Understanding and the Problem of Relativism in Gadamer's Philosophical Hermeneutics. Washington: The Council for Research in Values and Philosophy.

Bleicher, Josef. 2013. Hermeneutika Kontemporer: Hermeneutika Sebagai Metode, Filsafat dan Kritik, Terj. Ahmad Norma Permata. Yogyakarta: Fajar Pustaka.

Bukhârî. Imam, Abû 'Abdullâh Muhammad bin Ismâ'îl Al-Jâmi' ash-Shahîh li al-Bukhârî

Dâwûd. Abu al-Imâm al-Hâfizh al-Mushannif al-Mutqan Abî Dâwûd Sulaimân Ibnu al-'Asy'ats as-Sijistânî al-Azadî. Sunan Abî Dâwûd.

Fath al-Bâri bi Syarh Shahîh al-Imâm Ab̂̀ 'Abdullâh Muhammad bin Ismâ'îl al-Bukhârî

Grondin, Jean. 2013. Sejarah Hermeneutik Dari Plato Sampai Gadamer. Yogyakarta: Arruz Media.

Hadi, Abd. 2011. Hermeneutika Qur'ani dan Perbedaan Pemahaman dalam Menafsirkan AL-Qur'an, dalam jurnal Islamica, Vol. 6, No. 1, September.

Hakim. Abî 'Abdullâh al-Hâkim an-Naisâbûrî, Al-Mustadrak 'alâ ash-Shahîhayn

Ibrâhîm bin al-Mughîrah bin Bardizbah al-Ju'fî al-Bukhârî).

Ibrahim, Sulaiman. 2014. Hermeneutika Teks: Sebuah Wacana dalam Metode Tafsir Alquran, dalam Jurnal Studia Islamika "Hunafa", Vol. 11, No.1, Juni.

Jarîr. Ibnu Abû Ja'far ath-Thabarî bin Muhammad Jarîr bin Yazîd bin Katsîr bin Ghâlib al-Âmalî, Jâmi' al-Bayâni fî at-Ta'wîl al-Qurâni

Muslim. Imam Abî al-Husain Muslim bin al-Hajâj Ibnu Muslim al-Qusyairî an-Naisâbûrî. Al-Jâmi' ash-Shahîh li Muslim

Ulul Albab: Jurnal Studi dan Penelitian Hukum Islam 
Hermeneutika Emillio Betti .... 173

Nayed, Aref Ali. 1994. Interpretation as the Engagement of Operational Artifacts: Operational Hermeneutics. Universitas Guelph.

Palmer, Richard E. 1969. Hermeneutics: Interpretation Theory in Schleiermacher, Dilthey, Heidegger, and Gadamer. Evanston: North-Western University Press.

Poespoprodjo, W. 2004. Hermeneutika. Bandung: Pustaka Setia.

Rahman, Fazlur. 1982. Islam and Modernity. Chicago: University of Chicago.

Sa'd. Ibnu Sa'd az-Zuhrî al-Bashrî, Ath-Thabaqât al-Kubrâ

Seebohm, T.M. 2004. Hermeneutics; Method and Methodology. USA: Kluwer Academic Publishers.

Supena, Ilyas. 2008. Epistemologi Hukum Islam dalam Pandangan Hermeneutika Fazlur Rahman, dalam jurnal "Asy Syir'ah", Vol. 42, No. 2.

Supena, Ilyas. 2008. Epistemologi Tafsir; Relasi Signifed dan Signifer dalam Penafsiran Teks al-Quran, dalam jurnal "Teologia", Vol. 19, No. 1, Januari. 